\title{
Attitudes and Reactions of Medical Students to the Dissection Room
}

\author{
R. KHURSHID ${ }^{1}$, SADIA MAJEED ${ }^{2}$, LUBNA AMER ${ }^{3}$, SHAZANA RANA ${ }^{4}$, SADIA IKRAM ${ }^{5}$, SADAF SALEEM UPAL ${ }^{6}$ \\ Assistant Professor, Department of Biochemistry, Shalimar Medical and Dental College, Lahore \\ Assistant Professor Department of Pharmacology, Continental Medical College, Lahore \\ Associate Professor Department of Pharmacology, Fatima Jinnah Medical University Lahore \\ Associate Professor. Department of Pharmacology HITEC-IMS dental college Lahore \\ Associate Professor Department of Pathology, Azra Naheed Medical College, Lahore. \\ Associate Professor, Department of Biochemistry, Shalimar Medical and Dental College, Lahore \\ Correspondence to Dr. Sadia Majeed, Email: sadia.aimc@gmail.com, Cell: 0332-8242020
}

\begin{abstract}
Background: Students get their first experiences of dissecting human cadavers in the practical classes of anatomy. These experiences may help in their profession, but may also create some problems for students

Aims: To find out the attitudes and reactions of medical students to the dissection room.

Methods: A longitudinal study was conducted on 309 first year MBBS students at the local college of Lahore with no previous experience of cadaver dissection. Students were filled a questionnaire. The questionnaire designedwas based to identify the feelings and problems faced by the students in their first exposure to the human cadaver.

Results: Almost $25 \%$ students experience no symptom on first entry into the dissecting room. The commonest symptoms of $75 \%$ students were insomnia, dizziness, sweating, loss of appetite and palpitation. Other symptoms reported were breathlessness, skin irritation, irritation of the eye, etc. Focusing on task was the main coping strategy used by majority of students.

Conclusion: The majority of the students initially experience nausea and fear that may reduce with time while excitement and interest had increased on ensuing exposure to dissection.Study concluded that the negative effect of dissection room on students is less than the benefits of dissection of cadaver. Anticipation felt by the students to learn dissecting the cadaver was relatively high.

Keywords: Cadaver, Dissection room, Medical students.
\end{abstract}

\section{INTRODUCTION}

Teaching of Anatomy subject in medical Institutes based on the usage of human cadaveric specimens. As medical students start the medical course, they go through the anatomy course, which based on the contact with cadavers $^{1}$. Through dissection, students are able to grasp the three dimensional anatomy \& visualize firsthand knowledge of the human body².

A vast majority of students expressed a positive attitude toward the cadavers' dissection; Howevera small percentage of students for whom human dissection may be a traumatic experience and may cause a strongly negative experiencethat interfere with their study. The exposure include physical (smell, conjunctival irritation, nausea) and psychological (stress, anxiety and emotional trauma) ${ }^{3,4}$. Working with cadavers, weather visualization ofprosecuted specimens or through active dissection, causes stress to medical students ${ }^{3}$. Many studies reported that students feel stress after entering the dissection room and by cadaveric dissection. Whereas some student found no stress after seeing the cadaver dissection ${ }^{5,1}$. In many researches, problems faced by medical student in dissection room include revulsion at the smell and sight of the cadavers, infringement of cultural taboos, dehumanization and invasion of privacy ${ }^{6,7}$. Although the benefits of dissection for studying Anatomy is accepted worldwide the dissection of human cadaver is related with different forms of stresses ${ }^{8}$.

The study of anatomy is indivisible from cadaveric dissection. It involves the interaction of students with

Received on 27-12-2020

Accepted on 13-04-2021 cadavers and cadaveric material. The objective of this study was to determine the attitudes and reactions of medical students to the dissecting room.

\section{SUBJECTS AND METHODS}

A longitudinal study conducted on 309first year MBBS students at the college of Lahore city in year of 2019with no previous cadaver dissection. Student filled the questionnaire. , one questionnaire is based on factors related with unfavorable attitude of student towards dissection of cadaver with frequency of students, the odd ratio with $95 \%$ confidential interval. The $2^{\text {nd }}$ questionnaire is base on Symptoms by students after initial exposure followed by subsequent experience with dissection and revealed the frequency of students, the odd ratio with $95 \%$ confidential interval. The $3^{\text {rd }}$ questionnaire dealt with Coping mechanisms used by the students, expressed as frequency and relative frequency. The purpose of the study explained and consent obtained from the students.

Statistical Analysis: The data obtained from questionnaires were analyzed using SPSS version 20 . Variables were expressed in frequency and percentages.Factors associated with unfavorable Attitude of Medical Students towards Cadaver Dissection and Symptoms after initial exposure followed by subsequent experience with dissection was expressed as frequency, odd ratio and $95 \%$ Confidence Interval $(\mathrm{Cl}) . \mathrm{P}<0.05$ is taken as significant.

\section{RESULTS}


Fear to touch, to see the anatomical specimen, and fear of infection to cadaver dissection was measured by odd ration with $95 \% \mathrm{Cl}$. It is observed that odd ratio of events occurring in suffered students was significantly low $(\mathrm{P}<0.001)$ as compared to the odds of event observed in non-suffered group. Percentage of stress after examination of cadaver was $18 \%$ and after active dissection was $29 \%$ (data not shown). Besides the common symptoms of smell of the dissection room, students felt no symptom on first entry into the dissecting room. Other symptoms were insomnia, dizzines, sweating, loss of appetite and palpitation along with breathlessness, skin irritation, irritation of the eye, etc. (Table $1 \& 2$ ).

$28.1 \%$ students reported using coping strategies to combat the stress. About $22 \%$ students were trying to develop coping mechanism, which enables them to view cadaver. The mechanism of focusing on task was the main coping strategy used by $19.41 \%$ of students. Moreover, 7.11 praying for not taking tension. Lastly the opinion that cadaver helpful for learning the subject of Anatomy was 91.5\% (Table 3).

Any apprehension to cadaver dissection $(\mathrm{COR}=1.427,95 \%$ $\mathrm{Cl}$ : 0.846-2.408-0.922) were significantly associated with poor practice to cadaver dissection.

Table 1: Factors associated with unfavorable Attitude of Medical Students towards Cadaver Dissection

\begin{tabular}{|c|c|c|c|c|c|}
\hline Factors & Responses & Frequency & Odd ratio & $95 \% \mathrm{Cl}$ & P value \\
\hline $\begin{array}{l}\text { Fear after seeing anatomical } \\
\text { specimen } \\
\text { Fear to touch anatomical specimen } \\
\text { Fear of infection }\end{array}$ & $\begin{array}{l}\text { Yes } \\
\text { No } \\
\text { Yes } \\
\text { No } \\
\text { Yes } \\
\text { No }\end{array}$ & $\begin{array}{l}140 \\
169 \\
130 \\
179 \\
129 \\
180\end{array}$ & $\begin{array}{l}0.527 \\
0.513\end{array}$ & $\begin{array}{l}0.725 \\
0.701\end{array}$ & $\begin{array}{l}0.001 \\
0.001\end{array}$ \\
\hline $\begin{array}{l}\text { Depression: } \\
\text { After examination } \\
\text { After dissection }\end{array}$ & $\begin{array}{l}\text { Yes } \\
\text { No } \\
\text { Yes } \\
\text { No }\end{array}$ & $\begin{array}{l}57 \\
252 \\
219 \\
90\end{array}$ & $\begin{array}{l}0.051 \\
5.92\end{array}$ & $\begin{array}{l}0.076 \\
8.37\end{array}$ & $\begin{array}{l}0.001 \\
0.001\end{array}$ \\
\hline Feeling of sadness and sympathy & $\begin{array}{l}\text { Yes } \\
\text { No }\end{array}$ & $\begin{array}{l}122 \\
187\end{array}$ & 0.42 & 0.587 & 0.001 \\
\hline Neutral & $\begin{array}{l}\text { Yes } \\
\text { No }\end{array}$ & $\begin{array}{l}25 \\
284\end{array}$ & 0.007 & 0.013 & 0.001 \\
\hline Interest & $\begin{array}{l}\text { Yes } \\
\text { No }\end{array}$ & $\begin{array}{l}60 \\
249\end{array}$ & 0.058 & 0.086 & 0.001 \\
\hline
\end{tabular}

Table 2: Symptoms by students after initial exposure followed by subsequent experience with dissection.

\begin{tabular}{|c|c|c|c|c|c|}
\hline Problems/feelings & 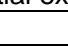 & Frequency & Odd ratio & $95 \% \mathrm{Cl}$ & P value \\
\hline Un bearable smell & $\begin{array}{l}\text { Yes } \\
\text { No }\end{array}$ & $\begin{array}{l}200 \\
109\end{array}$ & 3.36 & 4.68 & 0.001 \\
\hline Eye Irritation & $\begin{array}{l}\text { Yes } \\
\text { No }\end{array}$ & $\begin{array}{l}25 \\
284\end{array}$ & 0.007 & 0.013 & 0.001 \\
\hline Headache & $\begin{array}{l}\text { Yes } \\
\text { No }\end{array}$ & $\begin{array}{l}28 \\
281\end{array}$ & 0.009 & 0.017 & 0.001 \\
\hline Nausea & $\begin{array}{l}\text { Yes } \\
\text { No }\end{array}$ & $\begin{array}{l}15 \\
294\end{array}$ & 0.002 & 0.005 & 0.001 \\
\hline Sweating & $\begin{array}{l}\text { Yes } \\
\text { No }\end{array}$ & $\begin{array}{l}25 \\
284\end{array}$ & 0.007 & 0.013 & 0.001 \\
\hline Desire to leave dissection Hall & $\begin{array}{l}\text { Yes } \\
\text { No }\end{array}$ & $\begin{array}{l}15 \\
294\end{array}$ & 0.002 & 0.005 & 0.001 \\
\hline Insomnia & $\begin{array}{l}\text { Yes } \\
\text { No }\end{array}$ & $\begin{array}{l}30 \\
279\end{array}$ & 0.011 & 0.019 & 0.001 \\
\hline None of the above & $\begin{array}{l}\text { Yes } \\
\text { No }\end{array}$ & $\begin{array}{l}25 \\
284\end{array}$ & 0.007 & 0.013 & 0.001 \\
\hline
\end{tabular}

Table 3: Coping mechanisms used by the students

\begin{tabular}{|l|l|l|}
\hline Strategies & Frequency & $\%$ age \\
\hline Using coping strategies to combat the stress & 87 & $28.1 \%$ \\
\hline Trying to develop coping mechanism which enable to view cadaver & 68 & $22 \%$ \\
\hline Focusing of task & 60 & $19.41 \%$ \\
\hline Praying & 22 & $7.11 \%$ \\
\hline
\end{tabular}

\section{DISCUSSION}

Experience with dissection provides outlook of every part of human body, as it is not probable with plastic models, and help to understand the disparity in human body ${ }^{9}$.

According to our study, $25 \%$ students felt no symptom on first entry into the dissecting room. Our study is in contrast with number of studies. These study reported that that $80 \%$ of students suffered very little or no stress on the first visit to the dissection room. One of the study carried out in Eithopia found that large percentage of Eithopian students have bad responses to dissection 1 . Reports from Korean students showed that cadaver dissection is a significant and challenging life even ${ }^{10}$. 
We observed that the commonest symptoms were insomnia, dizziness, sweating, loss of appetite and palpitation. Other symptoms reported were breathlessness, skin irritation, irritation of the eye, etc.A study found that some Eithopianstudent showed physical symptoms including loss of appetite before go into the dissection room, and disturb by seeing the cadavers. Besides some students exhibited symptoms of faintness, sweating and dizziness ${ }^{11}$. Moreover, the study on Europian medical students showed that $46 \%$ of their students experienced fear, loss of appetiteprior and during the initial dissection ${ }^{12}$.

According to our study, the most common reason of their symptoms was the unpleasant smell of the dissection room, as reported by $64.72 \%$ of student. The findings also show that horror to touch the anatomical specimen, fear to see wasand fear of infection was.Many student reported feeling of sadness and sympathy. Percentage of stress after examination of cadaver was $18 \%$ and after active dissection was $29 \%$.A study demonstrated that $58.1 \%$ of students stated that the smell in the dissection room upset them ${ }^{1}$. Fear, sight and touch to anatomical specimenwere the main cause of symptoms as reported by $31.19 \%$ of Arab and students of European country ${ }^{13}$. It is proposed thatview and touch of the anatomical specimens may be a reason of disturbance due to the type of specimens used i.e. reproductive or brain specimen whomight have been upsetting to see ${ }^{14}$. In Nigeria, a study stated that some students found the dissecting room a most stressful place while the many students feel "mild" and "moderate" type of stress ${ }^{15}$. However, a study observed that more than half to the student found the dissection room very stressful?.

According to our study $28.1 \%$, students reported using coping strategies to combat the stress. About $22 \%$ students were trying to develop coping mechanism, which enables them to view cadaver. The mechanism of focusing on task was the main coping strategy used by $19.41 \%$ of students. Moreover, 7.11 praying for not taking tension. A study observed that coping strategies need more or less six weeks for reduction of nervousness and lack of concentration $^{8}$.Moreover, study carried out in Malaysia found that the most useful method of coping with anxiety was relaxation. Arab student coping the fear with rationalization and relaxation ${ }^{10}$. However Australian students coping mode was conversation with friends, fellow students and family members ${ }^{16}$. A study based on Nigerian Medical found that to alleviate the feeling of stress, majority of student busy in religious activities, or take a help of their teachers ${ }^{15}$

\section{CONCLUSION}

The majority of the students initially experience nausea and fear that may reduce with time while excitement and interest had increased on ensuing exposure to dissection.Study concluded that the negative effect of dissection room on students is less than the benefits of dissection of cadaver. Anticipation felt by the students to learn dissecting the cadaver was relatively high.
Study suggested that Instructors should give consciousnessbefore beginthe dissection session to the students both emotionally and mentally, ready to learn human anatomy confidently and enthusiastically.

Conflicts of Interests: None

\section{REFERENCES}

1. Getachew D. Reaction of medical students to experiences in dissection room. Ethiop J Health Sci. 2014;24(4):337-342. doi:10.4314/ejhs.v24i4.9

2. Park S, Kim Y, Park S, Shin JA. The impacts of threedimensional anatomical atlas on learning anatomy. Anat Cell Biol. 2019;52(1):76-81. doi:10.5115/acb.2019.52.1.76

3. Mulu A, Tegabu D. Medical students' attitudinal changes towards cadaver dissection: a longitudinal study. Ethiop $\mathrm{J}$ Health Sci. 2012;22(1):51-58.

4. Khan M and MirzaTM.Physical and psychological effects of cadaveric dissection on undergraduate medical students. JPMA 2013; 63(7):831-834

5. Leboulanger N, First cadaver dissection: Stress, preparation, and emotional experience,European Annals of Otorhinolaryngology, Head and Neck Dis 2011; 128 (4):175183 https://doi.org/10.1016/j.anorl.2011.01.007

6. Naz S, Nazir G, Iram S, Mohammad M, Qari IH, Mohammad $\mathrm{S}$. Perceptions of cadaveric dissection in Anatomy. J Ayub Med Coll Abbottabad 2011;23(3):145-148

7. Sándor I, Birkás E, \&Győrffy Z.The effects of dissection-room experiences and related coping strategies among Hungarian medical students. BMC Med Educ 2015;15:73. https://doi.org/10.1186/s12909-015-0355-9

8. Sharma S, Gupta VA. Study on the Approach of Medical Students Towards Cadaver in the Dissection hall. JK Sci 2017; 19 (3):187-190

9. Fredieu JR, Kerbo J, Herron M, Klate R, Cooke M. Anatomical Models: a Digital Revolution. Med.Sci.Educ 2015;25:183-194. https://doi.org/10.1007/s40670-015-0115-9

10. Chang HJ, Kim HJ, Rhyu IJ. Lee YM, Uhm CS. Emotional experiences of medical students during cadaver dissection and the role of memorial ceremonies: a qualitative study. BMC Med Educ 2018;18:255 https://doi.org/10.1186/s12909-018-1358-0

11. Abebe MS. Physical and emotional impact of cadaver dissection on innovative medical educationstudents: a survey in Ethiopia. Anatomy 2018;12(3):145-151

12. Nikhil M, Sabharwal R, Singhal V. Medical Students Embarking On Their Career With Cadaver Dissection. Eur J Mol\&Clin Med 2020; 7(7):4748

13. Bharadwaja $A$, \& Aman $M$. Cadaveric Dissection-lts Importance and Students Response: A Questionnaire Study. Int J Scientific Study 2017;252, 252. https://doi.org/10.17354/ijss/2017/435

14. Izunya AM, Oaikhena GA, \& Nwaopara AO. Attitudes to Cadaver Dissection in a Nigerian Medical School. Asian $\mathrm{J}$ Med Sci 2010;2(3):89-94.

15. Chia TI, Oyeniran OI, Ajagbe AO, Oluwanisola BT, Onigbinde OA, Tech B, Oraebosi Ml. The symptoms and stress experienced by medical students in anatomy dissection halls. J TaibahUni Med Sci 2020; 15(1):8-13

16. Hussein IH, Dany M, Forbes $W$, Barremkala $M$, Thompson BJ, \& Jurjus A. Perceptions of human cadaver dissection by medical students: A highly valued experience. Italian J Anat \& Embryol2015;120(3):162-171. https://doi.org/10.13128/lJAE17811 